\title{
1 Adaptive management of environmental flows
}

2 J. Angus Webb ${ }^{1, *}$, Robyn J. Watts ${ }^{2}$, Catherine Allan ${ }^{2}$, John C. Conallin ${ }^{3}$

$3 \quad{ }^{1}$ Department of Infrastructure Engineering, The University of Melbourne, Vic. 3010, Australia

$4 \quad{ }^{2}$ Institute for Land, Water and Society, Charles Sturt University, Albury, NSW 2640, Australia

$5{ }^{3}$ Department of Science and Engineering, IHE-Delft, 2611 AX Delft, The Netherlands

6 * angus.webb@unimelb.edu.au, + 6138344 9347, + 61383446215

7 Abstract: Adaptive management enables managers to work with complexity and uncertainty, and to

8 respond to changing biophysical and social conditions. Amid considerable uncertainty over the benefits

9 of environmental flows, governments are embracing adaptive management as a means to inform

10 decision making. This Special Issue of Environmental Management presents examples of adaptive

11 management of environmental flows and addresses claims that there are few examples of its successful

12 implementation. It arose from a session at the $11^{\text {th }}$ International Symposium on Ecohydraulics held in

13 Australia, and is consequently dominated by papers from Australia. We classified the papers according

14 to the involvement of scientists, managers and the local community in adaptive management. Six papers

15 provide examples involving water managers and researchers, and two papers provide examples

16 involving water managers and the local community. Five papers report on approaches developed by

17 scientists, and one paper on a community-led program. These case studies currently have little impact on decision making. There are no papers where researchers, managers and local communities all contribute to adaptive management. Successful adaptive management of environmental flows occurs

20 more often than is perceived. The final paper explores why successes are rarely reported, suggesting a

21 lack of emphasis on reflection on management practices. One major challenge is to increase the

22 documentation of successful adaptive management, so that benefits of learning extend beyond the

23 project where it takes place. Finally, moving towards greater involvement of all stakeholders is critical if

24 we are to realize the benefits of adaptive management for improving outcomes from environmental 25 flows.

26 Keywords: environmental flows, adaptive management, reflection, researchers, managers, local

27 stakeholders, decision-making, uncertainty, learning 
Freshwater systems are under heavy pressure from human use and are consequently highly degraded (Dudgeon et al. 2006). Governments around the world are turning to environmental flows - "the quantity, timing, and quality of water flows required to sustain freshwater and estuarine ecosystems and the human livelihoods and well-being that depend on these ecosystems" (Brisbane Declaration 2007) - to reduce these impacts (Horne et al. 2017). Environmental flows will play a key role in helping to meet the United Nations' Sustainable Development Goals (SDGs; UN 2017), especially SDG 6 - 'Clean Water and Sanitation' (Sood et al. 2017), and so go well beyond the ecological focus that has dominated thinking particularly in developed countries (e.g. Arthington 2012).

The science and implementation of environmental flows arose from, and has been dominated by, the concept of the natural flow paradigm (Poff et al. 1997). This states that a regulated flow regime should retain the full range of features of the pre-regulation flow regime if the system is to retain reasonable ecological function. This paradigm has recently been challenged by the acknowledgement that many regulated river systems today bear little resemblance to their former unregulated state, and that returning them to their original condition may be impossible or even undesirable. This has led to the concept of designer (Acreman et al. 2014) and functional (Yarnell et al. 2015) flows - flow regimes that are specifically designed to fulfil specific ecosystem functions that may or may not have been a feature of the river system in the past (Moyle 2014). There are thus several broad paradigms through which environmental flows may be conceived, along with a huge range of specific methods through which programs may be designed (Poff et al. 2017; Tharme 2003).

Implementation of environmental flows, however, remains a challenge. While environmental flows has proved an appealing concept for legislators and policy makers (Horne et al. 2017), and many countries have committed to providing water for the environment, the implementation of major environmental flows programs has lagged well behind these good intentions (Harwood et al. 2017; Le Quesne et al. 2010). One identified major barrier to implementation is the high uncertainty over costs and potential benefits of environmental flows (Moore 2004). Providing water for the environment often means removing water from traditional consumptive purposes (e.g. irrigated agriculture), either as reductions in allocations in highly-regulated systems, or restricting future development to prevent over-allocation in unregulated systems (Poff et al. 2003). It has been difficult for governments to legislate for the uncertain environmental benefits of flow provision compared to the more easily documented financial returns from consumptive uses. 
However the urgency of environmental degradation of rivers (Vorosmarty et al. 2010) compels governments to act despite far from perfect knowledge about how systems will respond. In such a setting, the practice of adaptive management is an obvious way forward to enable managers to work with complexity and uncertainty (Pahl-Wostl et al. 2013). Variously defined as 'learning by doing' and 'management under uncertainty' (Webb et al. 2017), adaptive management focuses on learning about and/or within a system to improve management outcomes for all stakeholders. The learning can also improve the overall state of knowledge about that type of system, potentially benefiting management in other similar systems. Adaptive management as an overarching concept is built into several major environmental flow programs, most notably the Murray-Darling Basin Plan in Australia, which seeks to return approximately $2750 \mathrm{GL}$ of water to the rivers of the Murray-Darling Basin (Hart 2016), approximately $20 \%$ of the amount previously used for consumptive purposes.

There are few examples of adaptive management of environmental flows in the academic literature. A search of the citation index Web of Science in mid-2017 identified only 73 publications, with 60 of these having been published since $2010^{1}$. This Special Issue, therefore, offered the opportunity to bring together for the first time papers regarding adaptive management of environmental flows to assess the state of the literature and the discipline, and to identify priorities for the future.

\section{Background to the special issue}

The Special Issue arose from a special session of the $11^{\text {th }}$ International Symposium on Ecohydraulics (ISE; Webb et al. 2016), held in February 2016, in Melbourne, Australia. Although submissions to both conference and Special Issue were open to any potential participant, the conference location created a bias towards papers from Australia.

Australia is a global leader in the implementation of large-scale environmental flows programs (Horne et al. 2017; Swirepik et al. 2016). The Murray-Darling Basin Plan, for example, is an approximate \$13B AUD investment in environmental restoration and associated programs, with \$3B AUD set aside for buybacks of irrigation water alone (Hart 2016; Skinner and Langford 2013). The large number of papers from Australia therefore may reflect this high level of government investment in environmental flows. Moreover, Australia being the driest inhabited continent has prompted water managers and researchers to develop innovative approaches to environmental water decision making that make the most of the

\footnotetext{
${ }^{1}$ Search carried out April 4, 2017, at the University of Melbourne. Search String: TS = ("adaptive manage*") AND ("environmental flow" or "environmental water" or eflow*)
} 
87 limited environmental water available (Horne et al. in review). Under such circumstances, methods that

88 rapidly incorporate improvements in our knowledge and understanding into decision making are particularly valuable. In the Web of Science search described above, author affiliations were also dominated by Australian institutions (number of authors: Australia 37, USA 29, Europe 15, South Africa 8). We were therefore comfortable that while the genesis of the Special Issue was the ISE conference, the Australian focus of this issue is in keeping with the forefront of research on adaptive management of environmental flows.

\section{Conceptions of adaptive management}

Since the concept of adaptive management was formalized in the 1970s (Holling 1978), it has evolved in several directions, and through different research traditions (Rist et al. 2013a; Rist et al. 2013b). In one direction lie approaches that are technically focused, relying on tight boundaries and restricted sets of possible decisions for the managed system. Statistical or mathematical models are heavily used to inform decisions, and monitoring and evaluation of the outcomes is used to update model parameters to improve the next round of decisions, and therefore ecological performance (e.g. Nichols et al. 2007; Runge et al. 2006). In the other direction lie approaches that consider the socio-ecological system, and place greatest value on the act of learning itself, and how this can help bring together the wide range of stakeholders in participatory management (e.g. Ostrom 2009; Wei et al. 2012). Both conceptions of adaptive management are valid, and most real world examples will lie somewhere along this continuum rather than being at either end.

Despite their differences, the two conceptions described above both consider adaptive management as a cyclical process consisting of the broad steps: plan, do, monitor, learn (Webb et al. 2017; Williams and Brown 2014). Within each of these major phases lies considerable complexity (Allan and Watts 2018), but this can be understood through the concept of 'mini-loops' consisting of iterative changes within the body of the adaptive management cycle (Fig. 1).

\section{Stakeholder contribution for successful adaptive management}

Volumes have been written on the 'failure' of adaptive management (e.g. Allan and Curtis 2005; Walters 2007; Westgate et al. 2013). Rather than recapitulate that literature in this paper, we bring together the papers in this Special Issue to offer some more detailed observations regarding one mechanism that is necessary for adaptive management to succeed in the long term. 
Regardless of the technical/social focus of an adaptive management program for environmental flows, we argue that adaptive management cannot succeed in the long term without the engagement of three different groups of stakeholders: water managers, researchers, and the local community. Water managers have understanding of the relevant legislation and regulations, and have the power to make the decisions; researchers have the specific knowledge of the technical or sociological methods needed to bring knowledge together; and the local community has considerable specific knowledge and understanding that can contribute to effective implementation and acceptance long-term.

The strengths and weaknesses of different balances of stakeholder engagement are explored pictorially in Fig. 2. We suggest that an ideal example of adaptive management would lie at the intersection of all three circles, and that good examples would involve two of the three stakeholder groups. The different regions of this Venn diagram represent different types of case studies that face different challenges to effective and sustainable adaptive management.

A. Models, approaches and tools developed entirely by researchers may have potential for use in adaptive management, but without manager and local community engagement during development may not be fit for purpose or achieve the requisite degree of 'ownership' for them to become successful. Case studies in this category are at greatest risk of being ignored, and thus falling into the 'Knowing-Doing Gap' recognized in many areas of applied environmental science (Knight et al. 2008).

B. Adaptive management programs run entirely by managers are unlikely to have the level of technical (or sociological) sophistication necessary to take advantages of the latest improvements in knowledge and systems (sensu Webb et al. 2010). Moreover, such schemes risk being perceived as too 'top-down' and may not achieve eventual local community acceptance or take advantage of local knowledge.

C. Adaptive management programs developed entirely by the local community will face challenges to gain acceptance by both managers and researchers. Like programs run entirely by managers (Region B), they may suffer from not taking advantage of the latest advances in research. On top of this, the local community may not have the power to compel managers to implement an adaptive management scheme.

D. Adaptive management programs that combine researcher knowledge with management engagement have a strong chance of being implemented and thus affecting management decisions. Over time, such schemes may be embraced by the local community (moving them 
into Region G), but if they do not, could potentially breed ill feeling among community stakeholders whose knowledge is not being used, and who are excluded from the decisionmaking process.

E. Adaptive management programs co-developed by local stakeholders and managers bring together the powerful combination of ownership and engagement. Such schemes can be implemented and affect decision making, but will likely lack the latest technical advances that engagement of researchers can bring. This could lead to a perception that management decisions are not being made using 'best available science' - something of a mantra in environmental management circles (Ryder et al. 2010).

F. A direct collaboration between researchers and the local community, but without the engagement of water managers, is perhaps the most difficult stakeholder scenario to envision. The main weakness would be that the stakeholders would not be in a position to influence decision making. However, should such a combination occur, we believe that it would have a strong chance of attracting manager support (and moving into Region $\mathrm{G}$ ) over time.

G. With true contributions and ownership by all three stakeholder groups, an adaptive management program would be able take advantage of the subject area expertise of researchers, whilst also achieving support from the local community and the benefit of their knowledge, and would have the necessary management support to effect real differences in decision making.

\section{How close to the ideal? Classifying case studies from the Special Issue}

Where do the papers from this Special Issue fit into the conception of stakeholder involvement presented in Fig. 2? We have mapped the papers from this Special Issue onto the stakeholder diagram (Fig. 3) using an iterative process. As editors of the Special Issue, we initially mapped each paper onto one of the seven regions. The first author of each paper was then sent a copy of the diagram that included only their study, and an explanation of its purpose. They were asked to comment and/or suggest a change to the mapping. While those suggestions were not always accepted completely, this resulted in some changes to our initial mapping.

The first obvious result from this process is that the great majority (11 of 14) of papers have a heavy involvement of researchers. This does not necessarily mean that the whole field of adaptive 
management is dominated by this group. Researchers are required to publish, and so case studies involving researchers are more likely to be published than those with minimal researcher involvement. Five of these 11 papers (Horne et al. 2018; Mcgregor et al. 2018; Ocock et al. 2018; Stewardson and Skinner 2018; Webb et al. 2018) are mapped to Region A (researcher only). While these papers present novel approaches to the science of adaptive management, the lack of involvement of other stakeholder groups means that they do not have a clear pathway to implementation. Most of these 11 papers have little involvement of local community stakeholders. The closest exceptions, Watts et al. (2018) and Vietz et al. (2018) have only minimal involvement of the local community, apart from local water managers.

Six case studies mapped to Region $D$, the intersection of researchers and managers. These include examples of decision making regarding flow allocations for the endangered Australian grayling in the Bunyip and Tarago rivers, Australia (Koster et al. 2018); managing the geomorphology and public perceptions of river bank erosion in the Goulburn River, Australia (Vietz et al. 2018); using irrigation water to provide critical refuges for native fish during low oxygen 'blackwater' events in the EdwardWakool system, Australia (Watts et al. 2018); and managing how return flows from wetlands are used to complement in-channel environmental flows while managing risk in the Murrumbidgee catchment, Australia (Wolfenden et al. 2018). These are four examples of adaptive management in action. Technical expertise of researchers, mixed with a willingness and ability to make adaptively informed decisions over short time scales by river managers, has resulted in real improvements for river health and environmental water outcomes. These decisions mostly correspond to the 'mini-loops' around implementation depicted in Fig. 1; there is less indication of adaptive processes being used to inform decision making at the yearly and longer scales. There are also two case studies that mapped to Region D where researchers have developed methods in collaboration with managers, with adaptive management as the ultimate goal (Hardie and Bobbi 2018; Koehn et al. 2018). Although these methods have not yet had major impacts on decision making, the collaboration of researchers and managers provides the clear pathway to implementation.

All of the above case studies are primarily based on the 'science framing' of adaptive management. Three case studies (admittedly two of which have the same primary author) mapped to the other side of the diagram, with the primary drivers being local community stakeholders, and a greater consequent focus on participatory processes and group learning.

Two case studies mapped to Region E, the intersection of managers and the local community. These include a successful example of participatory decision making in Tuppal Creek, Australia (Conallin et al. 
2018b); and the Columbia Basin Water Transactions Program, which tracks the implementation and impacts of water transactions (McCoy et al. 2018). Like those case studies that map to Region $D$, these example have good potential for long-term effective adaptive management, but would benefit from greater involvement of researchers to take advantages of latest advances in knowledge and to provide technical input and knowledge into the decision-making process.

The case study from the Edward-Wakool Strategic Adaptive Management (SAM) program (Conallin et al. 2018a) provides a sobering example of how continued engagement of all partners is necessary for successful adaptive management. The program was originally conceived as being within Region G; the community-driven program had support from management agencies (Office for Environment and Heritage, New South Wales Office of Water, Commonwealth Environmental Water Office), and involvement of researchers. During its first years of operation, the collaboration was influential for developing flow regimes designed to benefit different fish groups, which fed into decision making (Baumgartner et al. 2014). For various reasons, however, over time the water managers shifted their focus to other approaches for implementation and evaluation of environmental flows. While the SAM program is still used by the local community, it has had little recent influence on decision-making the in the Edward-Wakool system.

This example also illustrates that projects are not static; while we have mapped individual papers in this special issue to different regions of Fig. 2, those classifications could change over time, either to the benefit or detriment of adaptive management. Even successful examples of adaptive management require continued effort from all stakeholders to stay that way (Schreiber et al. 2004). From our point of view, that implies sustained effort and commitment from researchers, managers and the local community.

\section{Informality and the under-reporting of adaptive management}

Does the fact that we did not map any of the papers to the optimal Region $\mathrm{G}$ mean that such case studies do not exist? This brings us to the final paper in the Special Issue.

Allan and Watts (2018) does not appear on the stakeholder diagram, as this paper examines the process of adaptive management itself. The main finding is that adaptive management may manifest in multiple ways when there is commitment and trust from different stakeholder groups involved in managing a system (see also Webb et al. 2017). Such case studies are likely to be under-reported because of the very informality of some of the adaptive management taking place. As such, the 'failure' of adaptive 
management may be more a failure to document and report successful examples, with those examples not necessarily conforming to preconceived ideas of what adaptive management should look like. Several of the Region D case studies (Koster et al. 2018; Watts et al. 2018; Wolfenden et al. 2018) appear to be examples of this type of informal adaptive management. In each of these cases, management programs were put in place with the expectation of involvement by researchers, but there was no a priori expectation that adaptive management would take place. It is quite possible that these case studies would not have made their way into the literature but for the session at the 2016 ISE conference and subsequent opportunity to prepare a paper for this Special Issue. Furthermore, had these case studies been published without the focus of this Special Issue, they may have concentrated more on the scientific methods and results, and less on how these processes affected management decisions. Thus, this Special Issue has facilitated the publication of several cases of informal adaptive management that may otherwise have remained hidden.

This large number of successful case studies of adaptive management, highlighted through the mechanism of this Special Issue raises the possibility that adaptive management of environmental flows is occurring successfully in other parts of the world, but is not being reported. If this is the case, then the benefits of the learning taking place are not being shared with a wide audience. It also raises the possibility that ideal (i.e. Region G) cases of adaptive management of environmental flows exist, but are not being reported. In an April 2017 workshop on adaptive management within the Murray-Darling Basin Long-Term Intervention Monitoring Project (Gawne et al. 2013), we presented the stakeholder diagram. At least one of the programs (Warrego-Darling Rivers, NSW) claimed that adaptive management in that region fitted comfortably into Region G (P. Frazier, 2Rog Consulting, pers. comm.).

\section{Conclusion - Documentation and Dissemination - the role of Reflectors}

In recent work (Webb et al. 2017), we established a number of principles to underpin monitoring, evaluation and adaptive management of environmental flows. The final principle was a call for better documentation and dissemination of adaptive management programs. Better reporting of learning and outcomes would have two major benefits (Webb et al. 2017). First, it could help to counter the prevailing tone in the literature that adaptive management has failed to live up to its promise. This is important, as continued negative coverage of adaptive management could serve to undermine the faith that policy makers have thus far shown in it as a guiding principle for managing environments under uncertainty. Conversely, a redoubled commitment to 'learning by doing' could see renewed interest in 
protecting and restoring stressed environments despite considerable uncertainty over the best way forward. Second, better reporting of learning and outcomes would increase the rate of learning overall. Rather than learning simply taking place within a narrowly defined adaptive management program or team, wider dissemination of those learnings would allow other teams and programs to benefit from this hard-won knowledge, increasing the rate at which management of imperiled environments could improve and improving outcomes for all stakeholders.

Responsibility for this increased documentation and dissemination could rest with a type of team member new to adaptive management of environmental flows - a 'Reflector' (Webb et al. 2017). The idea of reflection in and on practice is not new, and builds on the seminal work of Schön (1983) and more recent systems practitioners (e.g. Ison et al. 2011). In our model, a Reflector would be responsible for continuous self-evaluation and reflection on the adaptive management project. Rather than being responsible for managing or collecting monitoring data, they would instead examine how well the adaptive management processes were working, and if necessary take steps to improve them. We understand that funding a team member to concentrate on this reflective role might be challenging amid limited budgets for monitoring, evaluation and adaptive management, but the potential gains are enormous.

We hope this Special Issue serves as a catalyst for increased discussion of adaptive management of environmental flows, and at the very least facilitates the documentation and discussion of other successful case studies from around the world. Adaptive management of environmental flows is an extremely young field. As we move into an ever-more hydrologically uncertain future (Milly et al. 2008), environmental flows will become increasingly important for sustaining river systems (Poff et al. 2016). But with increasing demand for water for both human and environmental purposes (Vorosmarty et al. 2010), innovative and robust management of environmental flow regimes will become increasingly important. Improved communication of what does and does not work in the adaptive management of environmental flows will help us to reach this point far sooner.

\section{Acknowledgements}

We thank the editorial staff of Environmental Management, and in particular Editor in Chief Bryan Brooks, for their forbearance during the extended gestation period of this Special Issue. The $11^{\text {th }}$ International Symposium on Ecohydraulics provided the catalyst for this Special Issue, and we thank the conference organizing committee for the opportunity provided. We thank both authors and reviewers of 
the case studies presented in this issue for their contributions and involvement. JAW's contribution to the Special Issue was supported by ARC LP130100174, and RJW's by a Research Fellowship from the Institute for Land, Water and Society at Charles Sturt University.

\section{References}

Acreman M et al. (2014) Environmental flows for natural, hybrid, and novel riverine ecosystems in a changing world Frontiers in Ecology and the Environment 12:466-473 doi:10.1890/130134

Allan C, Curtis A (2005) Nipped in the Bud: Why regional scale adaptive management is not blooming Environmental Management 36:414-425 doi:10.1007/s00267-004-0244-1

Allan C, Watts RJ (2018) Revealing Adaptive Management of Environmental Flows Environmental Management doi:10.1007/s00267-017-0931-3

Arthington AH (2012) Environmental Flows: Saving Rivers in the Third Millenium. University of California Press, Berkely and Los Angeles, CA

Baumgartner L, Conallin J, Wooden I, Campbell B, Gee R, Robinson WA, Mallen-Cooper M (2014) Using flow guilds of freshwater fish in an adaptive management framework to simplify environmental flow delivery for semi-arid riverine systems Fish and Fisheries 15:410-427 doi:10.1111/faf.12023

Brisbane Declaration (2007) The Brisbane Declaration. International Water Centre. http://www.watercentre.org/news/declaration. Accessed October 302017

Conallin J, McLoughlin CA, Campbell J, Knight R, Bright T, Fisher I (2018a) Stakeholder participation in freshwater monitoring and evaluation programs: applying thresholds of potential concern within environmental flows Environmental Management doi:10.1007/s00267-017-0940-2

Conallin J, Wilson E, Campbell J (2018b) Implementation of environmental flows for intermittent river systems: adaptive management and stakeholder participation facilitate implementation Environmental Management doi:10.1007/s00267-017-0922-4

Dudgeon D et al. (2006) Freshwater biodiversity: importance, threats, status and conservation challenges Biological Reviews 81:163-182

Gawne B et al. (2013) Long Term Intervention Monitoring Project: Logic and Rationale Document Version 1.0. Murray-Darling Freshwater Research Centre,

Hardie SA, Bobbi CJ (2018) Compounding effects of agricultural land use and water use in free-flowing rivers: confounding issues for environmental flows Environmental Management doi:10.1007/s00267-017-0836-1 
Hart BT (2016) The Australian Murray-Darling Basin Plan: factors leading to its successful development Ecohydrology \& Hydrobiology 16:229-241

Harwood A, Johnson S, Richter B, Locke A, Xuezhong Y, Tickner D (2017) Listen to the river: lessons from a global review of environmental flow success stories. WWF-UK, Woking, UK

Holling CS (1978) Adaptive environmental assessment and management. John Wiley \& Sons, Horne AC et al. (in review) Active management: can ecological outcomes be improved through alternative approaches to allocating environmental water? Journal of Water Resource Planning and Management

Horne AC, Szemis JM, Webb JA, Kaur S, Stewardson MJ, Bond N, Nathan R (2018) Informing environmental water management decisions: using conditional probability networks to address the information needs of planning and implementation cycles Environmental Management doi:10.1007/s00267-017-0874-8

Horne AC, Webb JA, Stewardson MJ, Richter B, Acreman M (eds) (2017) Water for the Environment: from Policy and Science to Implementation and Management. Elsevier, Cambridge MA

Ison R et al. (2011) Sustainable catchment managing in a climate changing world: new integrative modalities for connecting policy makers, scientists and other stakeholders Water Resources Management 25:3977-3992 doi:10.1007/s11269-011-9880-4

Knight AT, Cowling RM, Rouget M, Balmford A, Lombard AT, Campbell BM (2008) Knowing but not doing: Selecting priority conservation areas and the research-implementation gap Conservation Biology 22:610-617 doi:10.1111/j.1523-1739.2008.00914.x

Koehn JD, Todd CR, Zampatti BP, Stuart IG, Conallin A, Thwaites L, Ye Q (2018) Using a population model to inform the management of river flows and invasive carp (Cyprinus carpio) Environmental Management doi:10.1007/s00267-017-0855-y

Koster WM, Crook DA, Dawson DR, Gaskill S, Morrongiello JR (2018) Predicting the influence of streamflow on migration and spawning of a threatened diadromous fish, the Australian grayling Prototroctes maraena Environmental Management doi:10.1007/s00267-017-0853-0

Le Quesne T, Kendy E, Weston D (2010) The Implementation Challenge: taking stock of government policies to protect and restore environmental flows. The Nature Conservancy \& WWF,

McCoy AL, Holmes SR, Boisjolie BA (2018) Flow restoration in the Columbia River Basin: an evaluation of a flow restoration accounting framework Environmental Management doi:10.1007/s00267-0170926-0 
Mcgregor GB, Marshall JC, Lobegeiger JS, Holloway D, Menke N, Coysh J (2018) A risk-based ecohydrological approach to assessing environmental flow regimes Environmental Management doi:10.1007/s00267-017-0850-3

Milly PCD, Betancourt J, Falkenmark M, Hirsch RM, Kundzewicz ZW, Lettenmaier DP, Stouffer RJ (2008) Stationarity is dead: Whither water management? Science 319:573-574

Moore M (2004) Perceptions and interpretations of environmental flows and implications for future water resource management: a survey study. Linköping University

Moyle PB (2014) Novel aquatic ecosystems: the new reality for streams in California and other Mediterranean climate regions River Research and Applications 30:1335-1344

Nichols JD, Runge MC, Johnson FA, Williams BK (2007) Adaptive harvest management of North American waterfowl populations: a brief history and future prospects Journal of Ornithology 148 (Supplement 2):343-349

Ocock JF, Bino G, Wassens S, Spencer J, Thomas RF, Kingsford RT (2018) Identifying critical habitat for Australian freshwater turtles in a large regulated floodplain: implications for environmental water management Environmental Management doi:10.1007/s00267-017-0837-0

Ostrom E (2009) A general framework for analyzing sustainability of social-ecological systems Science $325: 419-422$

Pahl-Wostl C et al. (2013) Environmental flows and water governance: managing sustainable water uses Current Opinion in Environmental Sustainability 5:341-351

Poff NL et al. (1997) The natural flow regime BioScience 47:769-784

Poff NL et al. (2003) River flows and water wars: emerging science for environmental decision making Frontiers in Ecology and the Environment 1:298-306

Poff NL et al. (2016) Sustainable water management under future uncertainty with eco-engineering decision scaling Nature Climate Change 6:25-34 doi:10.1038/nclimate2765

Poff NL, Tharme RE, Arthington AH (2017) Evolution of environmental flows assessment science, principles, and methodologies. In: Horne AC, Webb JA, Stewardson MJ, Richter BD, Acreman M (eds) Water for the Environment: from Policy and Science to Implementation and Management. Elsevier, Cambridge MA, pp 207-241

Rist L, Campbell BM, Frost P (2013a) Adaptive management: where are we now? Environmental Conservation 40:5-18

Rist L, Felton A, Samuelsson L, Sandström C, Rosvall O (2013b) A new paradigm for adaptive management Ecology and Society 18:63 doi:10.5751/ES-06183-180463 
Runge MC, Johnson FA, Anderson MG, Koneff MD, Reed ET, Mott SE (2006) The need for coherence between waterfowl harvest and habitat management Wildlife Society Bulletin 34:1231-1237

Ryder DS, Tomlinson M, Gawne B, Likens GE (2010) Defining and using 'best available science': a policy conundrum for the management of aquatic ecosystems Marine and Freshwater Research 61:821-828

Schön DA (1983) The Reflective Practitioner: How Professionals Think in Action. Basic Books, New York Schreiber ESG, Bearlin AR, Nicol SJ, Todd CR (2004) Adaptive management: a synthesis of current understanding and effective application Ecological Management \& Restoration 5:177-182

Skinner D, Langford J (2013) Legislating for sustainable basin management: the story of Australia's Water Act (2007) Water Policy 15:871-894 doi:10.2166/wp.2013.017

Sood A et al. (2017) Global environmental flow information for the sustainable development goals. International Water Management Institute (IWMI), Colombo, Sri Lanka

Stewardson MJ, Skinner D (2018) Evaluating use of environmental flows to aerate streams by modelling the counterfactual case Environmental Management

Swirepik JL, Burns IC, Dyer FJ, Neave IA, O'Brien MG, Pryde GM, Thompson RM (2016) Establishing environmental water requirements for the Murray-Darling Basin, Australia's largest developed river system River Research and Applications 32:1153-1165

Tharme RE (2003) A global perspective on environmental flow assessment: Emerging trends in the development and application of environmental flow methodologies for rivers River Research and Applications 19:397-441

UN (2017) Sustainable development goals. http://www.un.org/sustainabledevelopment/sustainabledevelopment-goals/. Accessed October 302017

Vietz GJ, Lintern A, Webb JA, Straccione D (2018) River bank erosion and the influence of environmental flow management Environmental Management doi:10.1007/s00267-017-0857-9

Vorosmarty CJ et al. (2010) Global threats to human water security and river biodiversity Nature 467:555-561 doi:10.1038/nature09440

Walters CJ (2007) Is adaptive management helping to solve fisheries problems? Ambio 36:304-307

Watts RJ, Kopf RK, McCasker N, Howitt JA, Conallin J, Wooden I, Baumgartner L (2018) Adaptive management of environmental flows: using irrigation infrastructure to deliver environmental benefits during a large hypoxic blackwater event in the southern Murray-Darling Basin, Australia Environmental Management doi:10.1007/s00267-017-0941-1 
421 Webb JA, Costelloe JF, Casas-Mulet R, Lyon JP, Stewardson MJ (eds) (2016) Proceedings of the 11th International Symposium on Ecohydraulics. The University of Melbourne, Melbourne, Australia

Webb JA, Koster WM, Stuart IG, Reich P, Stewardson MJ (2018) Make the most of the data you've got:

424

425

426

427

428

429

430

431

432

433

434

435

436

437

438

439

440

441

442

443

444

445 Bayesian models and a surrogate species approach to assessing benefits of upstream migration flows for the endangered Australian grayling Environmental Management doi:10.1007/s00267017-0822-7

Webb JA, Stewardson MJ, Chee YE, Schreiber ESG, Sharpe AK, Jensz MC (2010) Negotiating the turbulent boundary: the challenges of building a science-management collaboration for landscape-scale monitoring of environmental flows Marine and Freshwater Research 61:798-807

Webb JA, Watts RJ, Allan C, Warner AT (2017) Principles for monitoring, evaluation and adaptive management of environmental flows. In: Horne AC, Webb JA, Stewardson MJ, Richter BD, Acreman M (eds) Water for the Environment: From Policy and Science to Implementation and Management. Elsevier, Cambridge MA, pp 599-623

Wei Y, Ison R, Colvin J, Collins K (2012) Reframing water governance: a multi-perspective study of an over-engineered catchment in China Journal of Environmental Planning and Management 55:297-318

Westgate MJ, Likens GE, Lindenmayer DB (2013) Adaptive management of biological systems: A review Biological Conservation 158:128-139 doi:http://dx.doi.org/10.1016/j.biocon.2012.08.016

Williams BK, Brown ED (2014) Adaptive management: from more talk to real action Environmental Management 53:465-479 doi:10.1007/s00267-013-0205-7

Wolfenden BJ, Wassens SM, Jenkins KM, Baldwin DS, Kobayashi T, Maguire J (2018) Adaptive management of return flows: lessons from a case study in environmental water delivery to a floodplain river Environmental Management doi:10.1007/s00267-017-0861-0

Yarnell SM et al. (2015) Functional flows in modified riverscapes: hydrographs, habitats and opportunities BioScience 65:963-972 


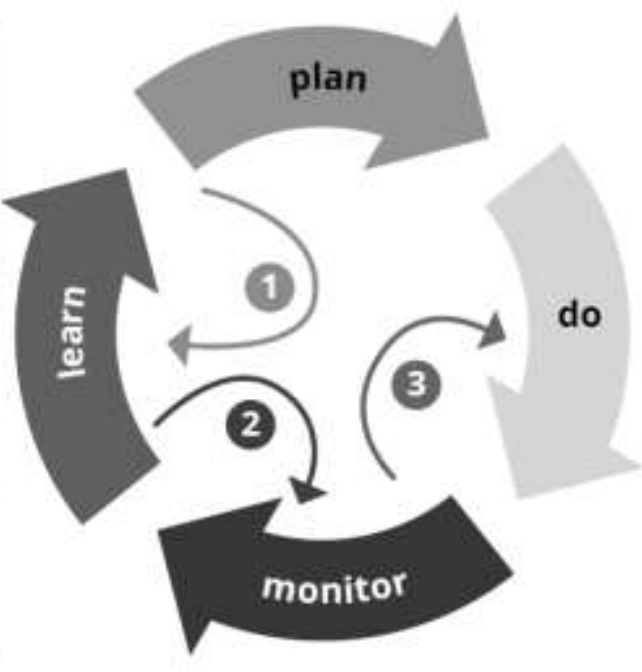

Outer learning cycle: Long-term goals, plans and actions are reviewed and modified in response to learnings

Inner learning loop 3: Aspects of implementation are refined in between planning reviews in response to monitoring

448 Fig. 1. The adaptive management cycle showing the outer learning cycle where lessons inform the next

449 formal phase of planning and implementation. The inner learning loops are small changes that are made

450 based on learnings that occur between major planning reviews. The inner loops effectively allow

451 progress in the outer loop in both directions. Reproduced from Webb et al. (2017). 


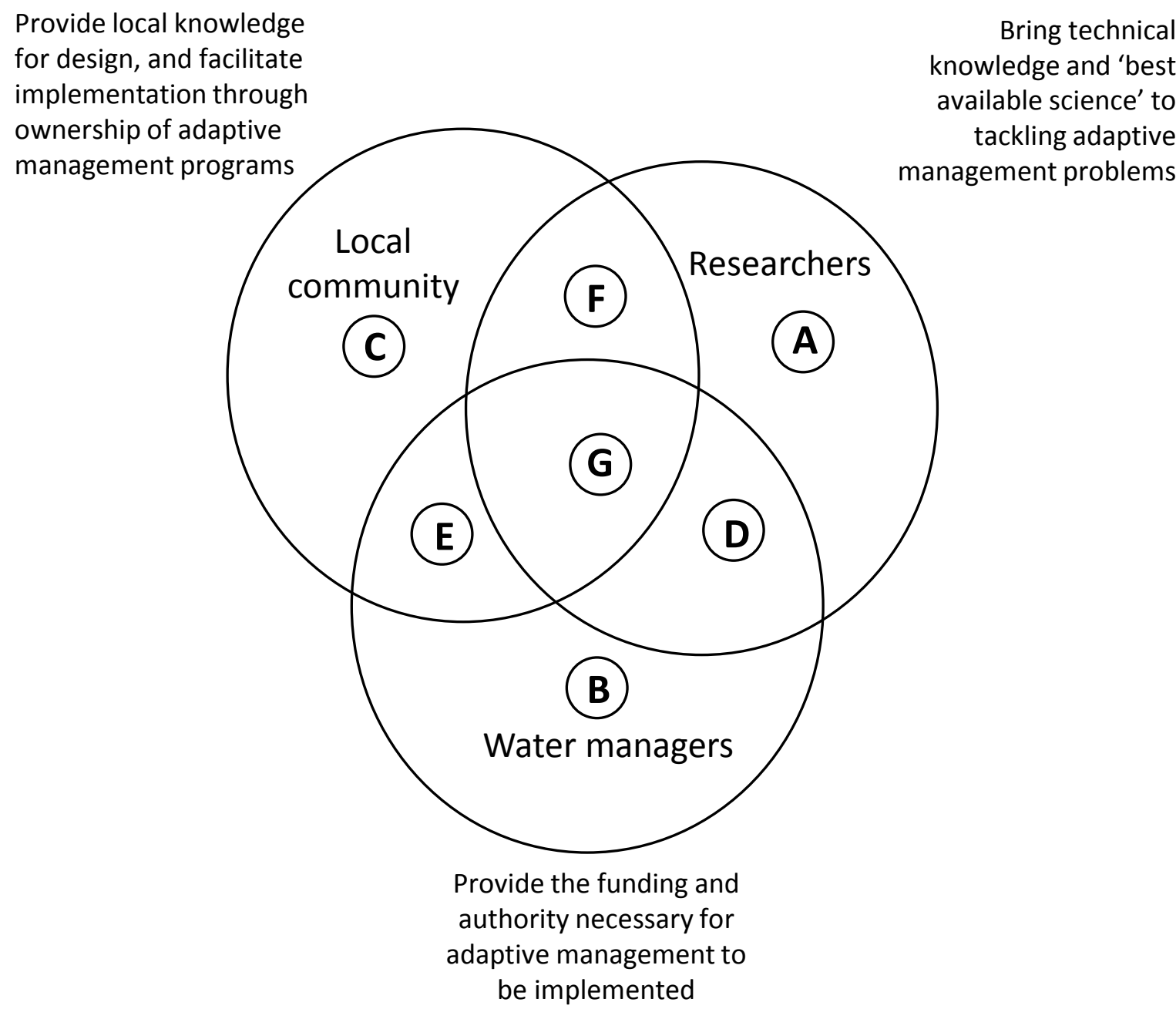
be implemented

453 Fig. 2. Three different groups of stakeholders are essential for successful adaptive management. The 454 figure depicts the different regions of interaction among the local community, researchers and water 455 managers to which the papers in this special issue are mapped (Fig. 3). Also included is a brief note on 456 what each stakeholder group brings to adaptive management, with these concepts covered more fully in 457 the main text. 


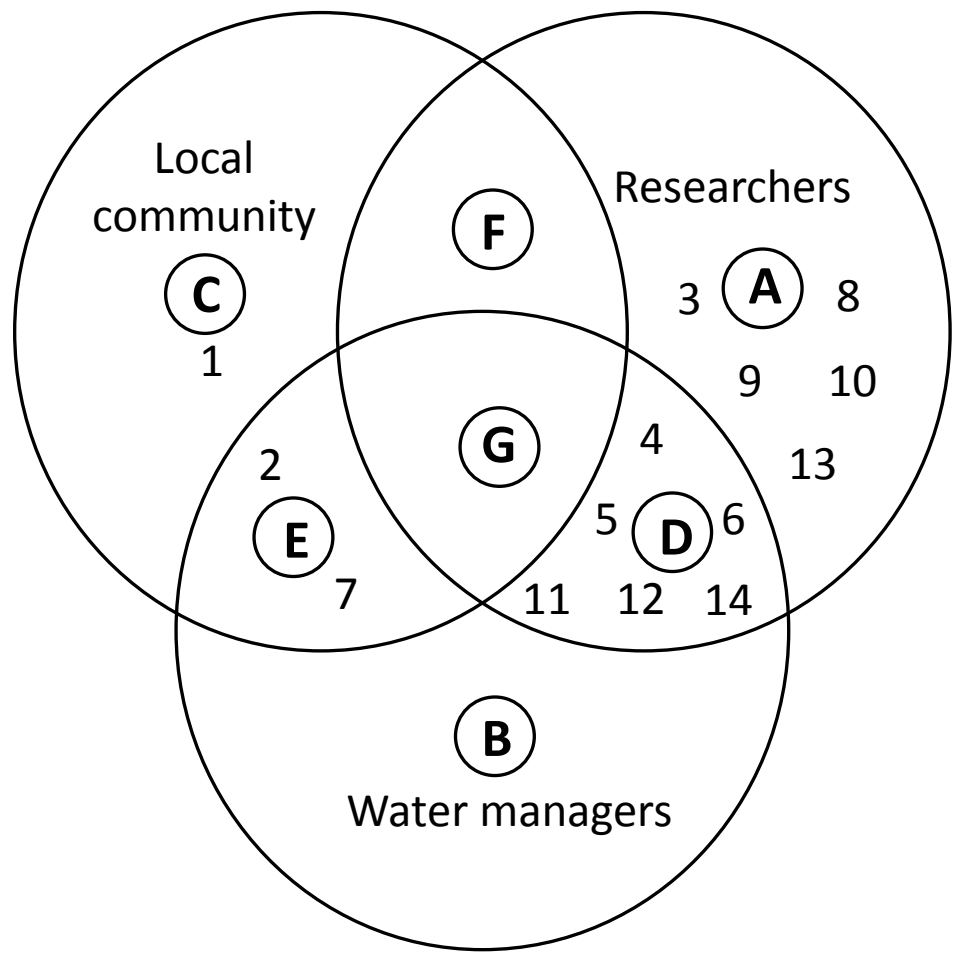

Region A. Researcher only

3. Horne et al. 2018

8. McGregor et al. 2018

9. Ocock et al. 2018

10. Stewardson \& Skinner 2018

13. Webb et al. 2018

Region C. Local community only

1. Conallin et al. 2018a

Region D. Researcher-Manager collaborations

4. Hardie \& Bobbi 2018

5. Koehn et al. 2018

6. Koster et al. 2018

11. Vietz et al. 2018

12. Watts et al. 2018

14. Wolfenden et al. 2018

\section{Region E. Local community-} Manager collaborations

2. Conallin et al. 2018b

7. McCoy et al. 2018

Fig. 3. Classifying the interaction of the local community, researchers and water managers for the papers

460 in this Special Issue. Mapping of each paper (indicated by digits) to a region (indicated by letter) in the

461 diagram was done in consultation with paper authors. Specific positions within regions are unimportant,

462 with discussion of finer-scale involvement of different stakeholder groups in the main text. Paper numbers were assigned in alphabetical order. 
473 < funding-group ><award-group id="IDOEYAAE3312"><funding-source funder-

474 id="http://dx.doi.org/10.13039/501100000923">Australian Research Council</funding-source ><award-

475 id >LP1300100174</award-id><principal-award-recipient><principal-award-recipient-first-

476 name>James</principal-award-recipient-first-name $><$ principal-award-recipient-middle-

477 name>Angus</principal-award-recipient-middle-name $><$ principal-award-recipient-last-

478 name>Webb</principal-award-recipient-last-name><orcid verified="yes">0000-0003-0857-

$4797878<$ /orcid $></$ principal-award-recipient $></$ award-group $></$ funding-group $>$

480

481

482

483

484

485

486

487 


\section{University Library}

\section{- M M I E R R V A gateway to Melbourne's research publications}

Minerva Access is the Institutional Repository of The University of Melbourne

Author/s:

Webb, JA;Watts, RJ;Allan, C;Conallin, JC

Title:

Adaptive Management of Environmental Flows

Date:

2018-03-01

Citation:

Webb, J. A., Watts, R. J., Allan, C. \& Conallin, J. C. (2018). Adaptive Management of Environmental Flows. ENVIRONMENTAL MANAGEMENT, 61 (3), pp.339-346. https:// doi.org/10.1007/s00267-017-0981-6.

Persistent Link:

http://hdl.handle.net/11343/283276 